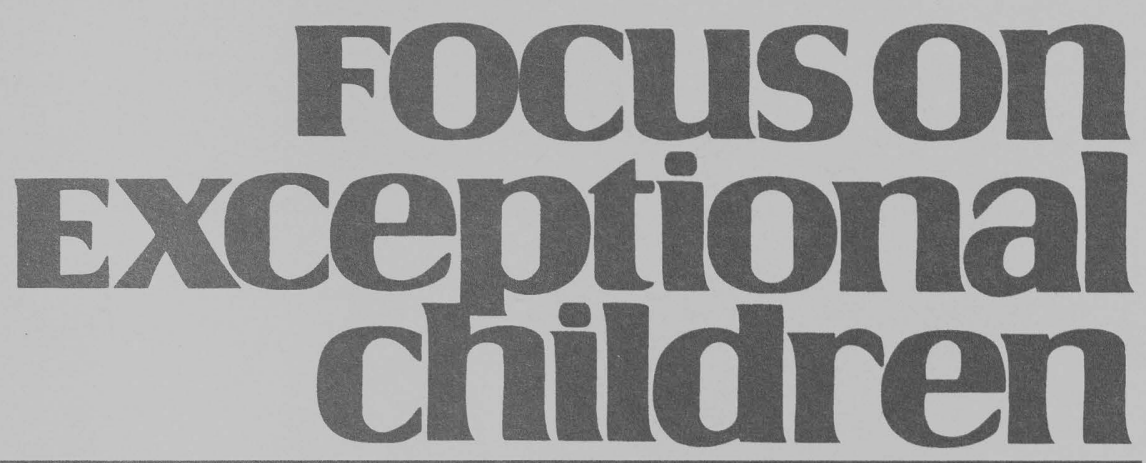

\title{
Special Education Teacher Supply and Teacher Quality: The Problems, The Solutions
}

\author{
Mary T. Brownell, Paul T. Sindelar, Anne G. Bishop, Lisa K. Langley, and Seonjin Seo
}

Special education is facing the daunting challenge of increasing the supply of teachers while simultaneously upgrading its quality. Shortages of fully qualified teachers have plagued special education for two decades, and schools also have struggled to find qualified math, science, and ESL teachers. Shortages in all of these fields are likely to worsen as the teaching workforce ages and as statewide initiatives (such as reductions in class size) fuel increased demand. The quality of the teaching workforce also has come under scrutiny, as schools across the country are initiating standards-based reforms in which teacher competence is linked to student performance on high-stakes assessments.

In this article, we first consider two policy initiatives that address the dilemma of increasing numbers and improving quality simultaneously. We then consider the problem of attrition, which contributes in significant ways to both the quantity and quality issues. We explain why attrition is a particular problem for beginning teachers and describe programs that have proven effective in combating it.

In response to burgeoning demand and dissatisfaction with the quality of the existing workforce, the Bush Administration has promulgated policies to increase supply, notably through the No Child Left Behind (NCLB) Act, the most recent authorization of what had been known as the Elementary and Secondary Education Act. These initiatives are designed to promote easy entry to the profession via alternative training routes for specific populations of teacher candidates.

Previously, the National Commission for Teaching and America's Future (NCTAF) had issued a policy blueprint in 1996 that addressed shortages and quality in a different manner, emphasizing the professionalization of teaching and the enhancement of schools as workplaces. It was argued that fewer teachers would leave the field-and more candidates would be attracted to it-if they were to teach at schools that would support their work and foster their professional growth, and if they were to earn a professional wage.

Mary T. Brownell is Associate Professor, Paul Sindelar is Professor, and Anne Bishop is Assistant Scholar. All three are with the Department of Special Education, University of Florida. Lisa Langley is a doctoral student in the School of Teaching and Learning and Seonjin Seo is a doctoral student in the Department of Special Education. 


\section{NO CHILD LEFT BEHIND}

No Child Left Behind (NCLB, 2001) is a policy package that focuses on statewide assessments, standards, and accountability. It also requires that all teachers be "highly qualified" by 2005-06, a challenge likely to necessitate dramatic change in state policy on teacher preparation and licensure. NCLB also lays the groundwork for such change. The act defines "highly qualified" teachers as individuals who hold full state licensure or who have a bachelor's degree and pass a state licensing examination. The emphasis in NCLB on alternative training routes is based upon the conviction that high-quality instruction places higher priority on content mastery than pedagogical training. Thus, teacher quality may be enhanced by attracting stronger candidates to the field. According to NCLB, stronger means better prepared in a subject area and having higher verbal ability.

The Administration has expressed its belief that formal teacher education programs have failed to produce the highly qualified teachers that NCLB demands and actually might discourage strong students from entering the field

\section{Focuson
Exceptional children}

ISSN 0015-511X

FOCUS ON EXCEPTIONAL CHILDREN (USPS 203-360) is published monthly except June, July, and August as a service to teachers, special educators, curriculum specialists, administrators, and those concerned with the special education of exceptional children. This publication is annotated and indexed by the ERIC Clearinghouse on Handicapped and Gifted children for publication in the monthly Current Index to Journals in Education (CIJE) and the quarterly index, Exceptional Children Education Resources (ECER). The full text of Focus on Exceptional Children is also available in the electronic versions of the Education Index. It is also available in microfilm from Xerox University Microfilms, Ann Arbor, MI. Subscription rates: Individual, \$36 per year; institutions, $\$ 48$ per year. Copyright (C) 2002, Love Publishing Company. All rights reserved. Reproduction in whole or part without written permission is prohibited. Printed in the United States of America. Periodical postage is paid at Denver, Colorado. POSTMASTER: Send address changes to:

$$
\begin{gathered}
\text { Love Publishing Company } \\
\text { Executive and Editorial Office } \\
\text { P.O. Box } 22353 \\
\text { Denver, Colorado } 80222 \\
\text { Telephone (303) 221-7333 }
\end{gathered}
$$

Karen Harris

University of Maryland
Thomas Skrtic University of Kansas

James Shriner University of Illinois

Erica J. Lawrence Editor
Stanley F. Love Publisher
(U. S. Department of Education, 2002). Supply may be enhanced by facilitating entry to the profession. In NCLB, this is achieved by allowing states to develop alternative entry routes. The Administration has characterized traditional teacher education and licensure as imposing high barriers and tolerating low standards. By contrast, NCLB simultaneously eliminates barriers to entry and raises standards for teachers.

\section{NATIONAL COMMISSION ON TEACHING AND AMERICA'S FUTURE}

What teachers know also figures prominently in the National Commission on Teaching and America's Future (NCTAF) policy blueprint, but so does what teachers $d o$. In this approach, teacher quality is fostered by program accreditation, initial licensure, and certification of accomplished practice. This approach recognizes the inadequacy of teacher education as it is commonly practiced today, but NCTAF advocates upgrading teacher education rather than fostering alternatives to it. In this plan, teacher quality is enhanced by improved professional preparation. In turn, improved professional preparation requires fundamental change in teacher education.

In "What Matters Most: Teaching for America's Future," NCTAF (1996) laid out a plan for teacher education reform. In it, teacher education is deferred until candidates receive bachelor's degrees. It emphasizes cognitive, social, and cultural foundations; a coherent program of mentoring and instruction, preferably at a professional development school; content pedagogy; and technology and teaming. Initial preparation is linked to high-quality professional development, and teacher practice in schools is organized to support their work.

It is thought that the quality of the work environment also figures into solving the problem of inadequate supply: By supporting teachers and fostering their professional growth, schools will lose fewer teachers to attrition. The plan includes additional initiatives designed to keep teachers in the field-among them, upgrading salaries and developing career ladders and other opportunities for advancement associated with advanced professional certification. NCTAF also argues for greater investment in quality teaching, an action that would reduce administration and increase the proportion of school professionals who work with children.

\section{COMPARISON OF THE TWO APPROACHES}

No Child Left Behind has much in common with "What Matters Most." Both plans support rigorous standards for students and teachers. Both stipulate that schools are responsible for the success of every student. Both seem motivated, 
at least in part, by a sincere concern about staffing highpoverty urban and rural schools. Both insist that schools hire only fully qualified teachers, and both recognize that teachers are underpaid. The two also differ in many ways, perhaps the most dramatic of which involves the role of teacher education. In "What Matters Most," upgrading teacher education is instrumental; in NCLB, alternatives are made readily available so that candidates may circumvent it.

To bolster supply, NCTAF advocates improving the job of teaching by (a) upgrading the profession, (b) improving the quality of the workplace, (c) supporting retention through mentoring and induction, and (d) basing teachers' salaries on knowledge and skills. NCLB provides more entry paths to teaching. Teacher education should be streamlined, and options to formal, campus-based training should be developed.

To improve teacher quality, NCTAF argues for better training. In this plan, all programs would be accredited, teachers would be held to rigorous standards, and teacher education would be more rigorous. The quality enhancement strategy implicit in NCLB is to recruit better trainees. Individuals with higher verbal ability and with stronger content preparation may be recruited into streamlined programs from which unnecessary and trivial requirements have been eliminated.

\section{THE SPECIAL EDUCATION CONTEXT}

The urgency of developing and sustaining an adequate special education teacher workforce is heightened by two factors:

1. The persistence of teacher shortages

2. The high level of attrition from the field.

Special education has had teacher shortages since the inception of the Education for All Handicapped Children's Act (1975), and there is little to suggest that this scenario might improve. The Bureau of Labor Statistics (1999) projected demand for more than 135,000 special additional education teachers between 1998 and 2008. Shortages also seem to be pervasive across states, with only a few states (e.g., Connecticut and Massachusetts) having no shortages and other states having rather dramatic shortages. In fact, according to the U.S. Department of Education (USDOE) (2001), more than half of Wyoming's special educators are uncertified. Shortages also vary by geographic location within states and by disability areas, with poor urban and rural schools and emotional and behavioral disorders experiencing the most severe shortages (American Association for Employment in Education, 1999; Ingersoll, 2001; National Center for Education Statistics, 1997; Riley, 1998).
Another aspect of the shortage issue is the underrepresentation of teachers from culturally and linguistically diverse (CLD) groups. In 1998, 14\% of special education teachers were CLD, compared to $25 \%$ of the general population and $37.5 \%$ of all special education students (USDOE, 2001). Furthermore, the percentage of CLD teachers is predicted to drop to $12 \%$ by the year 2009 (Olson, 2000). Given the dramatic, chronic, and multifaceted nature of shortages in special education, it is not yet clear what impact NCLB's requirement for highly qualified teachers will have on our field, but policy makers (West, 2002) expect the new law to present a serious dilemma for schools as 2005-06 approaches.

An insufficient supply of new special education teachers, increasing student enrollments, a shrinking reserve pool (i.e., the number of teachers not currently employed), and high teacher attrition rates in special education contribute prominently to chronic shortages (McLeskey, Smith, Tyler, \& Sanders, 2002). In 1998, 22,250 newly certified teachers graduated from teacher preparation programs to fill the 30,000 vacant special education positions that year (USDOE, 1998). Although the number of graduates had increased by nearly 4,000 since 1993 , a shrinking supply from the reserve pool offset positive growth in graduation rates. An analysis of data from two Schools and Staffing Surveys (SASS) suggested that between 1990 and 1993 the percentage of new hires from the reserve pool dropped by $17 \%$.

At the same time, growth in the population of students with disabilities and high teacher attrition rates in special education put considerable strain on states to provide an adequate supply of certified teachers. From 1992 to 1999 , the nation's student population (aged 3 to 12 ) grew by $6.8 \%$; at the same time, the number of special education students grew by $20.3 \%$. The number of special education teachers who leave the field annually also outstrips the numbers of available new hires. In the most recent analysis of the SASS data, the number of special educators who left teaching more than doubled the number of new graduates from teacher education programs.

We can only speculate about the reasons for an inadequate supply of special education teachers. Some scholars assert that insufficient pay and poor working conditions undoubtedly affect teachers' decisions to enter and remain in the field. We do have some information about successful recruitment strategies and some research that documents why teachers-particularly beginning teachers-leave the field. In the sections to follow, we describe factors related to the attrition of general and special education teachers and consider why beginning teachers are most vulnerable. We also review strategies that states, districts, and schools have employed to recruit and retain teachers, and how some of 
these strategies simultaneously increase teacher quality. In doing so, we hope to provide school practitioners with information about what states, districts, and institutions of higher education might do to promote better recruitment and retention of qualified teachers.

\section{MAJOR FACTORS CONTRIBUTING TO SPECIAL EDUCATION ATTRITION}

An analysis of Schools and Staffing Survey data from 1987-88, 1990-91, and 1993-94, showed that the overall attrition rate for special educators was $6.1 \%$ compared to $5.7 \%$ for general educators. In addition, in 1990-91, special education lost teachers through transfer to general education. Although the net loss was only 5,264 teachers, the 14,559 special education teachers who transferred to general education represented more than $5 \%$ of the special education teaching force (Boe, Cook, Bobbit, \& Weber, 1996).

Special education teachers abandon careers in the classroom for many reasons. Research over the past decade or so indicates that factors related to teacher attrition in special education seem to cluster into three major areas:

\section{Teacher characteristics \\ 2. Workplace conditions \\ 3. Affective responses to teaching.}

In the following sections we describe factors in these three areas that affect teachers' career decision making and highlight supporting research. For a more thorough review of these factors and others, we refer readers to major literature reviews by Billingsley (1993, 2002), and Brownell and Smith (1992).

\section{Teacher Characteristics}

Individual teacher attributes and their relationship to attrition have been studied extensively in the general education literature and to a somewhat lesser extent, in special education. In both general and special education, researchers have examined the relationship of age, experience, race, academic ability, and certification to teacher attrition. Although, in one or more studies, each of these variables has been related to teacher attrition, age, experience, and certification status have been the most consistent predictors of a teacher's decision to leave the classroom. More recent research in general education suggests that the preparation route a teacher takes also may influence retention; this research, combined with research on certification status, suggests that teachers' preparation for the classroom makes a difference in their decisions to remain.

Young, inexperienced teachers are the most vulnerable to attrition and most in need of extra support. National, state, and local studies have shown that young, inexperienced teachers are more likely to either leave the classroom or indicate an intention to leave than are their more experienced counterparts.

In a national study of special and general education teachers, Boe, Barkanic, and Leow (1999) found that earlyyear teachers were the most vulnerable to attrition and that risk for leaving dropped dramatically with experience. Both general and special education teachers in their first 2 years voluntarily left the classroom at a rate of about $8 \%$. Voluntary attrition rates dropped to $5 \%$ for teachers with 7 to 13 years of experience and $2.5 \%$ for teachers with 14 to 22 years of experience.

Researchers collecting state and local data on special education teachers have consistently supported these findings (Cross \& Billingsley, 1994; Miller, Brownell, \& Smith, 1999; Morvant et al., 1995; Singer, 1993), suggesting that inexperienced teachers are a district's greatest risk for attrition. What is unclear in this research is how age and experience are interrelated in predicting attrition, as most inexperienced teachers also are young.

Not being fully certified for a main assignment puts general and special education teachers both at risk for attrition. Boe and his colleagues (1999) found that teachers who did not hold a certificate for their main assignment were twice as likely as those who were fully certified to leave the classroom or move to another classroom. Other studies at the national and state levels also have found that certification matters in decisions to remain in or leave the classroom. Carlson and Billingsley (2001) found in a national study of special education teachers that certification status was a significant indicator of intention to leave, and Miller et al. (1999), in their statewide study of Florida's special education teachers, found that certification status was one of the strongest predictors of a decision to leave the classroom or transfer to another school or district.

Research on traditional and alternative preparation routes has demonstrated that program duration affects retention of general education teachers. For instance, Andrew and Schwab (1995) reported that graduates of 5-year teacher education programs were more likely to remain in teaching than were graduates of 4-year programs. In a national study of college graduates, Henke, Chen, Geis, and Knepper (2000) found that teachers who entered the classroom without student teaching - a common route for untrained teachers and those entering via shortened routes-left the profession at nearly twice the rate of those who had completed training.

Darling-Hammond (1999) also found that graduates from 4- and 5-year programs were more likely to remain in the classroom than were graduates from short-duration alternative routes. She reported that attrition rates for individuals 
entering teaching through shortcut programs (e.g., bachelor's degree plus intensive summer training in a teaching field) were about $60 \%$, compared to $30 \%$ for traditionally trained teachers and $10 \%$ to $15 \%$ for graduates of 5 -year programs (Berry, 2001; Darling-Hammond, 1999). In contrast, longer duration alternative programs have demonstrated impressive retention rates (Southeast Center for Teaching Quality, 2002). These data combined with retention data for graduates of 4- and 5-year programs demonstrate that preparation contributes positively to teacher retention.

\section{Working Conditions}

Teachers are motivated or discouraged by the quality of their work environment. Salary, school climate, administrative support, and issues related to the role special education teachers play in schools have an impact on their decisions to stay or leave. When special educators believe they are adequately compensated for their efforts, in terms of both the intrinsic and the extrinsic rewards they receive, they are more likely to remain in the classroom.

\section{Teacher Salary}

How much money teachers make influences attrition and retention. Overall, teachers who earn more tend to remain in teaching and are less mobile than those who earn less. All other things being equal, attrition and mobility rates decline with increasing salary levels (Boe et al., 1999). Correlations between salary and attrition rates for districts are strongest at the top and bottom of the salary distribution. Hare and Heap (2001) found that Michigan, the state with the highest average salaries in the nation (after cost-of-living adjustments), had the lowest proportion of districts reporting difficulties in retaining teachers $(21.9 \%)$, whereas, in Iowa, the state with the lowest average salaries adjusted for costof-living expenses, $44 \%$ of districts reported high rates of turnover.

Although the relationship between salary and attrition is strong, it is mediated by several factors, including opportunities to earn more in nearby districts, employment options outside of teaching, and working conditions. Teachers are more likely to quit teaching or transfer to another position when their salaries are low relative to salaries in nearby districts (Pogodzinski, 2000). Moreover, when salaries are comparatively low, other risk factors emerge. For example, the lowest paying districts lose teachers at a greater rate, and administrators in these districts are often left with few hiring options. In lower paying districts, administrators find themselves hiring more uncertified teachers than affluent districts, increasing the risk for attrition.

Even if districts could raise salaries, they may not be able to overcome attrition problems, particularly if higher paying job alternatives are available and working conditions are poor. When teachers have more opportunities to secure higher paying jobs outside of teaching, they are more likely to leave. The availability of higher paying job alternatives is the reason math and science have greater teaching shortages and urban districts have greater attrition than rural districts (Hanushek, Kain, \& Rivkin, 2001). Undoubtedly, economic opportunities for teachers in urban areas are greater than those available in rural areas, where teaching may be the most attractive employment option.

\section{Intrinsic Rewards of Teaching}

The quality of a teacher's work life is often more important than a teacher's desire to earn more money. A study from the National Bureau of Economic Statistics showed that teachers would be willing to take a pay cut to transfer to schools where students would be more capable academically and where teachers would receive more resources to do their job (Hanushek et al., 2001). Similarly, Miller et al. (1999) found that school climate and perceived stress were much stronger predictors than salary of special education teacher attrition, even though teachers who earned less were more likely than their higher paid colleagues to leave.

From the special education teacher's viewpoint, workplace quality plays a crucial role in career decisions. Do special educators believe that their school is a good place to work? Is the environment safe for them and their students? Do they feel part of the mainstream? Answering no to these questions places special educators at risk for leaving the classroom. In fact, in statewide and national studies of special education teachers, school climate proved to be one of the strongest predictors of teacher attrition or movement to another school (Carlson \& Billingsley, 2001; Miller et al., 1999).

Although we do not know all the factors that contribute to a positive school climate, support from an administrator undoubtedly is one of them. When teachers feel supported by their administrators, they are more likely to believe that their school is a good place to work and persist in the classroom. In special education, the amount of administrative support available at the building and district levels is a strong indicator of teachers' commitment to teaching and their decisions to remain in the field (Billingsley, 2002; Boe et al., 1999; Gersten, Keating, Yovanoff, \& Harniss, 2001; Miller et al., 1999).

Having a clear sense of one's role in the school and a manageable workload also improves a special education teacher's commitment to teaching. Special education teachers may be burdened by unreasonable job responsibilities and contradictory expectations from parents, administrators, and their general education colleagues (Kozleski, Mainzer, \& Deshler, 2000; Mastropieri, 2001). Over the past 4 years, special education teachers' workloads have increased by 
approximately 22\% (Carlson, Schroll, \& Klein, 2001; USDOE, 1998, 2000).

Moreover, changing student demographics and movement toward noncategorical services have resulted in more diverse caseloads for special educators. Special educators seem capable of handling more students, but increasing numbers combined with increasing diversity becomes less manageable. In a national study of special education teachers, Carlson and Billingsley (2001) found that teachers who served students with different disabilities felt the most overwhelmed by their job and expressed a strong intention to leave special education. Adding to their sense of burden is the excessive paperwork that many special education teachers must complete to meet federal and state regulations (Billingsley, Pyecha, Smith-Davis, Murray, \& Hendricks, 1995; Schnorr, 1995; Westling \& Whitten, 1996).

Increasing pressure to include students with disabilities adds to special educators' sense of role conflict and ambiguity. Some special educators are frustrated by general educators' resistance to inclusion (Billingsley \& Tomchin, 1992; Boyer \& Lee, 2001; Carter \& Scruggs, 2001). Others experience conflict when placed in roles where their primary responsibility is to collaborate with general educators rather than to provide direct services to students (Embich, 2001; Morvant et al., 1995). In this case, special educators may feel deprived of the opportunity to do what they prepared themselves to do- teach. Moreover, special educators experience heightened anxiety and conflict when colleagues and principals do not make the education of students with disabilities an important focus in the school or do not provide sufficient professional growth opportunities (Gersten et al., 2001). Support and professional development undoubtedly help special educators feel better able to handle the challenges of their jobs.

\section{Affective Responses to the Job}

When special educators face undesirable working conditions day after day, their commitment to teaching, satisfaction with the job, and stress are likely to change for the worse, increasing the chances that they will leave the classroom (Billingsley \& Cross, 1992; Cross \& Billingsley, 1994; Gersten et al., 2001; Morvant et al., 1995; Singh \& Billingsley, 1996). Conversely, when teachers feel that principals communicate openly, demonstrate their leadership, establish trust, and show appreciation for their efforts, teachers are more satisfied with their jobs (Cross \& Billingsley, 1994; Singh \& Billingsley, 1996). On the one hand, excessive paperwork, high caseloads, and frequent meetings cause many special educators to feel stressed and less committed to their workplace. On the other hand, the longer teachers work, the more able they are to handle the organizational demands of their job. Indeed, classroom experience is linked to higher levels of professional commitment (Cross \& Billingsley, 1994).

\section{WHY ARE BEGINNING SPECIAL EDUCATION TEACHERS MOST VULNERABLE TO ATTRITION?}

Teaching is one of the few professions where novices are expected to meet the same demands as their more seasoned colleagues. "Similar to their more experienced colleagues, beginning teachers must plan lessons, teach content subjects, manage student behavior, collaborate with peers, communicate effectively with parents, and complete paperwork" (Brownell \& Skritic, 2002, p. 5). These challenges are enormous when one considers that beginning teachers have not yet developed basic classroom routines and are just starting to operationalize their knowledge of instruction.

Beginning special education teachers face the same challenges as all beginning teachers-and then some. Paperwork requirements, development of instructional and testing accommodations, IEP development and implementation, and collaboration all fall within the purview of special educators, novices and veterans alike (Billingsley \& Tomchin, 1992; Boyer \& Gillespie, 2000; Brownell \& Skrtic, 2002; Kilgore \& Griffin, 1998; MacDonald, 2001). Moreover, they are likely to have fewer colleagues at their schools and less chance for consistent mentoring. Beginning special educators also believe that they must face these demands with fewer curricular and technological resources than those available to their general education colleagues (Griffin, Winn, Otis-Wilburn, \& Kilgore, 2002). Given the nature of their work and the supports they receive to do it, it is little wonder that beginning special educators question whether they can meet the demands of the job.

Some beginning special educators do not have the basic knowledge or skills to overcome the challenges they face. Inexperienced special educators are far less likely to be fully certified for their main position than are their more experienced counterparts. In a national study of beginning special education teachers, Billingsley (2001) found that only $63 \%$ of first-year teachers were fully certified for their job, compared to $91 \%$ of teachers in their fifth year. Although being uncertified places any teacher at risk for attrition, it is more problematic for beginners. High attrition rates among young, inexperienced special education teachers emphasize the vulnerability of this group and the need to consider strategies that will increase the likelihood of their remaining in the field.

\section{STRATEGIES FOR RETAINING SPECIAL EDUCATION TEACHERS}

We believe that policy and practice at the state and local levels may be designed to make teaching special education 
a more desirable career. We also believe that combating attrition would help to reduce chronic shortages. Most states and districts have paid less attention to retention than to recruitment, and, indeed, recruitment strategies may improve retention, particularly if they increase the numbers of fully certified teachers entering the classroom. Research suggests, however, that improving the preparation and induction of new teachers and the working conditions of all teachers may be more successful.

In this section, we describe state and district policies that hold potential for decreasing attrition. We provide information about the characteristics of alternative preparation and induction programs that also seem to be effective in improving retention rates. We then describe research studies that examine school environments with high retention rates for the purpose of identifying supports they provide to teachers.

\section{State and District Strategies for Recruiting Certified Teachers}

Long before No Child Left Behind, concern over dramatic shortages in the upcoming decade had produced a flurry of state- and district-level strategies for special education teacher recruitment. States and districts are instituting expensive, aggressive recruitment strategies, such as innovative internet recruitment sites, signing bonuses, compensatory pay for working in critical-shortage areas or hard-to-staff schools, loan forgiveness, and increases in teacher salaries.

In this section we provide some examples of the strategies districts and states are employing. Before we do, however, we must acknowledge that if we have fewer fully qualified special education teachers than special education jobs, no recruitment policy, however aggressive, will solve this problem nationally.

In this case, such policies may work only to shift the shortage burden from one school, district, or state to another. But if recruitment policy is designed to increase the number of individuals entering preparation programs, or to increase the number of general education teachers migrating to special education or of reserve pool members returning to teach, such policies would supplement total supply and not merely shift the burden of demand. Although this is an important distinction to bear in mind, we must recognize at the same time that states are obligated to provide a fully qualified teaching force and that state policy is designed to solve state and not national problems.

Aggressive recruitment strategies hold some promise for increasing the number of qualified special education teachers in a district or state. Web-based advertising seems to be an excellent tool for recruiting new teachers, particularly out-of-state teachers. In the Oregon Special Education Recruitment and Retention Project (2002), a survey of newly hired special education professionals revealed that more than half had found their current jobs over the internet and that more than $60 \%$ of out-of-state new hires were experienced special educators. Clark County School District in Las Vegas has developed an innovative recruitment website that sells the benefits of living in Las Vegas. In addition, 65 district representatives visit school districts nationwide to recruit teachers. In 1998, these recruitment strategies yielded an applicant pool of 4,500 qualified teacher candidates.

Other districts and states offer financial incentives to attract and retain teachers (Southeast Center for Teaching Quality, 2002). Pennsylvania recently instituted a $\$ 3.8$ million recruitment program to pay signing bonuses - equal to $20 \%$ of a teacher's starting salary - to teachers willing to work in high-shortage areas (i.e., special education, math, science, and foreign language). New York, South Carolina, Mississippi, California, Louisiana, and Massachusetts all provide a variety of incentives to recruit teachers to hard-tostaff schools and critical-shortage areas. For example, New York provides an annual stipend of $\$ 3,400$ to any certified teacher who takes a job in a critical-shortage area. Mississippi provides tuition scholarships to teachers who are willing to work toward a master's degree in a critical-shortage area and also assists with relocation costs.

Despite the enormous expense of these strategies, there is little evidence of their effectiveness in attracting or retaining teachers, and there is some indication that the strategies are not effective in attracting qualified teachers to hard-to-staff schools. New York's bonuses and aggressive recruitment strategies do seem to be increasing the overall supply of certified teachers, but South Carolina and Massachusetts have seen less success despite an enormous expenditure of recruitment funds. In South Carolina, an $\$ 18,000$ signing bonus was effective in recruiting only $20 \%$ of the teachers needed to fill 500 positions. Teachers either were not sufficiently qualified or were unwilling to move to hard-to-staff schools.

In contrast, previous research on salary and teacher attrition has supported raising salaries to attract and retain qualified teachers. On average, teachers earn $20 \%$ less than professionals in other occupations requiring similar levels of education. Recognizing the problem, Louisiana, West Virginia, Iowa, Alabama, Arkansas, North Carolina, and Connecticut have enacted legislation to increase salaries. Despite these efforts, Connecticut is the only state that has completely eradicated teacher shortages (Southeast Center for Teacher Quality, 2002). Thus, a closer examination of Connecticut's policy context may provide insights into how better to recruit and retain special education teachers.

\section{Connecticut's Comprehensive Policy Initiative}

Connecticut has enacted the best example of a comprehensive policy initiative to address teacher shortages, 
through careful attention to improving teacher quality much as NCTAF has proposed. After analyzing policies across the 50 states and conducting an indepth case study of Connecticut, Wilson, Darling-Hammond, and Berry (2001) found that the state's efforts to raise teacher quality represented the most notable, long-term, systemwide reform effort undertaken by any state to ensure quality teaching for all schools. Even though more than 25 states have passed legislation designed to improve teacher recruitment, education, certification, or professional development, only Connecticut has developed a policy approach to address them coherently.

Nearly 30 years ago, Connecticut's state department and legislature began to consider what might be done to address inequities in the learning outcomes of students from various socioeconomic backgrounds. They equalized school funding and created policies to ensure an adequate supply of qualified teachers for all schools. The state provided funds for increases in teacher salaries, incentives to attract highability teachers, and incentives for districts to hire certified teachers. It enacted a law prohibiting the hiring of uncertified teachers and began a strategic effort to educate the citizens about public education.

Along with these incentives, the state department of education worked collaboratively with colleges of education, district administrators, and teachers to develop high standards for teacher knowledge and performance aligned with state standards for student learning. A three-tiered teacher certification system (beginning, provisional, and professional certification) was established to ensure teachers' continuous progress toward these standards. To acquire a Beginning Certificate to practice in schools, potential teachers must pass a basic skills test and a test of knowledge in subject matter. To achieve Provisional Certification, teachers must successfully complete an induction program that includes rigorous evaluation and extensive mentoring. Professional Certification requires that all teachers with 2 or more years of successful teaching experience participate in 90 hours of professional development every 5 years for renewal.

To ensure that licensure standards were not just another hollow requirement, Connecticut implemented several strategies to support learning opportunities for teachers. The state designed and implemented one of the most impressive statewide teacher induction programs in the country, the Beginning Educator Support and Training Program (BEST). In BEST, beginning teachers are evaluated, according to state standards, over 2 years and receive considerable mentoring to meet those standards. To align standards for teaching and student learning, the state department provides data about student performance on indepth, low-stakes assessments of reading, writing, and mathematics. These data are made available to districts with the expectation that they will become the foundation for all professional development activities. In a study conducted by the National Education Goals Panel, Baron (1999) concluded that Connecticut's use of low-stakes, authentic assessment and its ability to make these data easily accessible to districts for further analysis are the keys to its impressive student achievement gains.

In addition to providing data, the state department provides supports to high-need districts, such as additional funds for professional development, preschool and all-day kindergarten, and smaller pupil-teacher ratios. More recently, Connecticut placed increasing emphasis on developing instructional leaders to support teachers' efforts in schools. The state is working with the Interstate School Leadership Licensure Consortium to create standards that emphasize the central role that teaching expertise plays in the development of instructional leaders who can foster teacher learning.

Connecticut's efforts to align teaching and administrator standards with standards for student learning combined with the ongoing provision of supports for teacher learning provide the foundation for one of the most coherent, continuous systems of teacher education in the country. Moreover, Connecticut has demonstrated that raising salaries, increasing teacher standards, and providing multiple learning supports can increase teacher quantity and quality. Compared to $43.7 \%$ nationally, more than $80 \%$ of all the state's teachers hold master's degrees (National Center for Educational Statistics, 1997), and in 1990 approximately $30 \%$ of new hires graduated from highly selective colleges or universities.

More important, rising student NAEP scores (at least for nondisabled students) over the past two decades indicates that this system of promoting teacher learning is successful. Although we do not know how these reforms specifically affected special education teachers, we do know that Connecticut reports no shortages in this area. Clearly, Connecticut's efforts to raise salaries, increase teacher standards, support beginning teachers, and improve teacher quality have "helped create a culture that value[s] teachers and teaching" (Wilson et al., 2001, p. 34). Moreover, the results of these efforts are so impressive in terms of student achievement that the public is willing to continue supporting them even during hard economic times.

\section{High-Quality Alternative Routes}

Alternative preparation routes also hold potential to increase the number of individuals particularly those from diverse backgrounds, entering the teaching profession (Zeichner \& Schulte, 2001). Moreover, a small amount of existing research suggests that some of these programs produce competent graduates who are likely to remain in teaching. Clearly, alternative programs have been highly successful in recruiting culturally and linguistically diverse (CLD) 
students, and, because they do not compete with formal teacher education program for traditionally college-aged students, most programs contribute uniquely to the supply of new teachers.

In reviews of research on alternative programs in general and special education, Rosenberg and Sindelar (2001) and Zeichner and Shulte (2001) cited high proportions of CLD participants as a notable accomplishment. For example, in the Pathways to Teaching Careers program sponsored by the DeWitt Wallace-Reader's Digest Fund (Focus: Pathways, 2002), $79 \%$ of the participants in the paraprofessional program are minorities. Haberman (1999) found that $78 \%$ of the participants in the Milwaukee Metropolitan Teacher Education Program were minorities.

\section{Programs for Paraprofessionals}

One particularly promising approach for recruiting more diverse teacher candidates and improving retention rates involves training paraprofessionals. Districts typically offer these "step-up" programs in collaboration with campusbased teacher education programs (Epanchin \& WooleyBrown, 1993; Gaynor \& Little, 1997). To date, programs of this sort described in the literature are "alternative" only in the sense of student demographics and the venues at which courses and field experiences are offered. Participants tend to be older than traditional college age and more experienced; they also are more likely to be first in their families to get college degrees.

Courses and field experiences are offered off campus, most often in schools in host districts. These programs do not offer shortcuts into teaching and often are as rigorous as traditional special education teacher preparation. Most participants in step-up programs enter with no college degree and complete a minimum of 2 years of preparation. They are likely to have extensive experience with children and actually may be identified and selected on the basis of their classroom competence.

Graduates often go to work in districts (and sometimes schools) where they previously were employed as paraprofessionals. Those who do so come equipped with knowledge of the community, school routines, and district rules and regulations, and they can be counted on to hit the ground running. They tend to be stable members of their communities and are less likely to move than are younger teachers who have yet to put down roots.

Common sense suggests that retention may be less an issue for these individuals, and research bears this out. California has been offering paraprofessional step-up training for more than a decade. Between 1995 and 2001, 311 teachers graduated from such programs, and as of $2002,99 \%$ had remained in the field (Southeast Center for Teaching Quality, 2002).
It is not surprising that "grow your own" programs such as these are becoming popular and widespread. For example, the Dewitt Wallace-Reader's Digest Fund has invested \$45 million in its Pathways Program for paraprofessionals (and returning Peace Corps volunteers). The program has graduated more than 2,000 "scholars," as they are called, from 42 colleges and universities nationwide, and retention is estimated to be $90 \%$ (Focus: Pathways, 2002). Retention rates of both programs are considerably better than rates for both 4- and 5-year teacher preparation programs.

In special education we have similar examples funded through the Office of Special Education Programs (OSEP). Most of the graduates of the VCUF Program, an OSEP-supported collaborative program we conducted with the Volusia County (Florida) schools, have remained in the field. At last count, 5 years after completing the program, 16 of 19 graduates were teaching, all in Volusia County (Rennells, Sindelar, \& Austrich, 1997).

In addition to improving retention rates, step-up programs and other more intensive alternative preparation programs show promise of graduating competent teachers (Focus: Pathways, 2002; Sindelar, Rennells, Daunic, Austrich, \& Eisele, 1999). In a comprehensive study of alternative and traditional programs (Sindelar et al., 1999), we used PRAXIS III to assess the competence of alternatively and traditionally trained graduates. PRAXIS III is a comprehensive assessment using observational and interview data to document how well beginning teachers plan and deliver instruction, organize their classrooms, and communicate with parents and other professionals. In a comparison of graduates of campus-based programs to two types of alternative programs - those offered through a university and district partnership and those offered by a district alone, special education graduates of step-up programs and campus-based programs were more skilled than graduates of programs offered exclusively by districts (Sindelar et al., 1999). Also, initial evaluations of the Pathways Program graduates demonstrated that graduates have achieved at least an average level of competence on all components on Praxis III (Focus: Pathways, 2002).

\section{Programs for Career Changes}

Other promising models of alternative preparation involve intensive, post-baccalaureate preparation to accommodate second-career professionals or non-education majors. These programs typically require students to participate in extensive coursework, provide mentoring by both university faculty and experienced classroom teachers, and involve collaboration between teacher education programs and school districts. Although little research has examined the effectiveness of these approaches, two studies in general and special education suggest that these programs produce competent teachers. 
One such program is ALTCERT, offered collaboratively by the Johns Hopkins University and Baltimore County Schools (Rosenberg \& Rock, 1994) and sponsored by OSEP. ALTCERT is a post-baccalaureate program for individuals with degrees and experience in other fields; it is based on Johns Hopkins's Master's-level teacher education program. Initial evaluations provided by special education supervisors and principals suggested that graduates of this program compared favorably to graduates of the campus-based program.

Miller, McKenna, and McKenna (1998) studied an alternative program for middle school teachers similar in structure to ALCERT. They compared graduates of this program to graduates of more traditional, campus-based programs and found them to be similar on an observational measure of classroom practice and in promoting student achievement.

Other alternative programs truly are abbreviated and expedite entry into the classroom. These shortcut programs differ dramatically from other alternative routes, as well as from traditional, campus-based programs, and the impact of these programs on retention and teacher quality is less clear. One well-known example is Teach to America (TFA). Like ALTCERT, this program is geared to attract career changers.

TFA. TFA offers recent college graduates-non-education majors - a 5-week summer institute and 1- or 2-week orientation before placing them in high poverty urban and rural schools, where they serve as teachers. Candidates obligate themselves to serve 2 years, during which time they receive formal support and additional training. Over the past 12 years, TFA has placed more than 8,000 teachers in 12 communities nationwide.

Despite the impressive number of teachers this program has placed, several research studies have called into question the effectiveness of the program. For one thing, TFA graduates have high attrition rates-more than $60 \%$-and two studies questioned how adequately prepared TFA graduates are to teach. In a study comparing teachers from alternative routes to those from traditional routes, DarlingHammond, Chung, and Frelow (2002) found that TFA graduates were less satisfied with their preparation programs and did not feel as well prepared on a variety of classroom practices. Laczko-Kerr and Berliner's (2002) study of alternative route and traditional route teachers demonstrated that TFA graduates and other undercertified teachers were less effective than graduates of traditional routes in promoting student achievement.

TTT. Troops to Teachers (TTT) is a U. S. Department of Education program, authorized through 2006 by the No Child Left Behind Act. A support program more than a training program, TTT provides financial incentives to encourage retiring military personnel to enter teaching. Like TFA,
TTT graduates agree to serve in high-need districts-in this case for 3 years. They also have 3 years to obtain a teaching license. A nationwide network of offices offers support in finding employment and training.

Since its inception in 1994, TTT has supported roughly 3,000 retirees who went on to teach. It is notable that the vast majority of them are men $(90 \%)$, that minority representation is higher (29\%), and that more TTT graduates pursue careers in special education than expected. The success of this program in providing a more diverse workforce, retaining teachers, and fostering effective classroom practice has received some support in initial evaluation studies (National Center for Education Information, 1998; Webber, Raffeld, \& Kettler, n.d.). TTT graduates have retention rates equivalent to graduates of 5-year programs (e.g., $85 \%$ to $87 \%$ of these teachers remain in the field), and administrators tend to rate TTT graduates comparably to graduates of traditional programs (National Center for Education Information, 1998; Webber et al., n.d.).

Comparing TTT and traditionally trained teachers, however, should not be construed as a test of alternative route training. Indeed, many TTT teachers complete a post-baccalaureate or master's program to obtain their teaching license.

Given that the supply of graduates from formal teacher education programs is inadequate to meet the demand for new teachers and that burgeoning shortages loom on the horizon, alternative routes represent a viable strategy for increasing the supply. Although little can be said with certainty about alternative routes generally, some programs have been shown to produce competent teachers. They do bring into the field individuals for whom traditional, campus-based programs seem inappropriate-second career professionals and retired military personnel, for exampleand they can help to diversify the teaching workforce. In our judgment, these are significant accomplishments.

The term "alternative route" encompasses a wide range of programs, and research to date has been limited to more extensive and rigorous ones. The verdict remains out on shortcut programs.

\section{Induction Programs}

High-quality induction has the potential to combat many of the challenges that confront beginning special education teachers as they enter the field. Although the primary purpose of induction is to help beginning teachers become more effective, good induction may contribute to teachers' decisions to remain in teaching. In fact, both general education and special education beginning teachers who participate in carefully designed programs, nested in a supportive working environment, are far more likely to become our veteran teachers of tomorrow. 
Here, we identify the critical characteristics of high-quality induction programs for both general and special education teachers and highlight successful state and local efforts. We emphasize the importance of workplace conditions, recognizing that environments in which teacher learning is valued and supported also foster retention of both early career and veteran teachers.

Induction may be defined as a planned process of support (Griffin et al., 2002). Induction programs often are tailored to the specific needs of a jurisdiction or group and vary dramatically by design and definition. In their review of the induction literature, Griffin et al. (2002) drew from the earlier work of Moskowitz and Stephens (1996) and identified key characteristics of quality induction programs for both general and special education teachers. These characteristics were (a) a culture of shared responsibility and support, (b) interactions between new and experienced teachers, (c) a continuum of professional development, (d) de-emphasized evaluation, (e) clear goals and purposes, (f) rich instructional and pedagogical content, (g) mentoring, and (h) fiscal and political support. By addressing these key elements, interested states, districts, and collaborative partnerships have the ingredients for establishing effective induction programs.

Although the key characteristics identified by Griffin et al. (2002) are important components of induction programs for all teachers, some additional factors must be considered to address the specialized needs of special educators (Billingsley, 2001; Whitaker, 2000). Beyond the typical planning, management, and curricular issues, special education teachers also must wrestle with caseload management, collaboration, parental issues, accommodations, and paperwork. These burdens often are specific to a particular school culture (Griffin et al., 2001; Whitaker, 2000; White \& Mason, 2001). Mentors offering individualized and contextual support must address the specialized challenges typically faced by early special educators (Rosenberg, Griffin, Kilgore, \& Carpenter, 1997; White \& Mason, 2001).

According to Griffin and her colleagues, effective features of mentoring programs in special education include (a) frequent contact between mentor and mentee, (b) nonevaluative support, (c) formal and informal support, (d) good mentor match, and (e) appropriate content of support. Special education teachers are different; they require mentors who focus on the their individual concerns and teaching context in a consistent, positive, nonevaluative manner. For a more thorough review of the guidelines for special educator mentorship, we refer readers to the Council for Exceptional Children website, http://www.cec.sped.org

Many states, districts, and collaborative partnerships have incorporated these key characteristics into induction and mentoring programs to support and retain beginning teachers. The National Association of State Directors of Teacher Education and Certification (NASDTEC) (NASDTEC, 2000, 2002) reports that 26 states and the District of Columbia provide some level of support for beginning teachers. Another report indicates support from as many as 28 states and the District of Columbia (Southeast Center for Teacher Quality, 2002). Although support from the state level seems to be increasing and some programs provide evidence of success, a review of beginning teacher induction programs for both general and special education indicates that programs vary dramatically according to level of funding, accessibility, and intensity of support (Southeast Center for Teacher Quality, 2002; Hirsch, Koppich, \& Knapp, 1998; 2001).

When examining successful induction programs, two key elements clearly surface. The schools, districts, states, and collaborative partnerships highlighted in the induction literature exhibit a high level of commitment to teacher learning and provide adequate fiscal support. It is not surprising that schools that support teacher learning, foster collegiality, and promote professionalism also recognize the importance of nurturing early-career teachers. And fiscal commitment is vital in providing ongoing support for beginning teachers. A report from the Southeast Center for Teacher Quality (2002) indicated that the average cost for many of the most effective programs is $\$ 5,000$ to $\$ 8,000$ per teacher. It would be fair to assume that this price tag may be a bargain compared to the organizational costs that districts incur in replacing teachers.

Many local and state induction initiatives recognize the importance of funding initiatives to retain the teachers who already are on board. Connecticut, however, emerges as an exemplar in teacher retention, and its induction program is no exception (Wilson et al., 2001). The BEST Program represents Connecticut's commitment to teacher quality by serving as a change agent for new teachers and mentors alike. Beginning teachers are offered levels of support over 3 years and also are held to high subject-specific standards assessed by classroom observations and portfolios. For example, the portfolio for second-year teachers consists of lesson plans, videotapes, reflection, and student work samples. Trained state assessors who are familiar with the Connecticut Teaching Competencies and the Connecticut Competency Instrument Indicators evaluate this portfolio.

Further, mentors or cooperating teachers are trained and often involved in other levels of professional development such as training as the state assessor. Not surprisingly, mentors report improvements in their own teaching, which is consistent with other studies reporting this value-added effect (Gibb \& Welch, 1998). Connecticut's induction program exemplifies its comprehensive commitment to improve teaching and learning. 
We are beginning to gain evidence outside the state of Connecticut that induction is dramatically reducing the attrition rates among new teachers. For example, the California Beginning Teacher Support and Assessment program (BTSA) has reduced attrition rates among all new teachers by $66 \%$ (Berry, 2001). In a comparative analysis, attrition rates varied from $9 \%$ to $37 \%$, based on availability of the BTSA induction program. Similarly, by providing comprehensive induction programs, districts in Ohio, including Cincinnati, Columbus, and Toledo, reduced attrition rates by more than two thirds (Darling-Hammond, 1997). Clearly, schools, districts, and states that exemplify the concept of learning communities and emphasize the development of early career teachers are better positioned to retain highly qualified professionals.

Whereas induction programs have the potential to support and retain new teachers in the field, high-quality mentoring alone obviously is subverted by an unhealthy workplace environment. In a 3-year evaluation of four mentoring programs in the Baltimore City Public School System (BCPSS), Silva and Silva (2001) concluded that school culture was the critical factor in determining whether a teacher remained with the BCPSS over the short- or long-term. Although three-fourths of the teachers interviewed in the study considered mentoring as useful, school culture dominated beginning teachers' decisions to leave or to remain in teaching. With this in mind, we now examine teachers' working conditions and highlight the elements of effective schools and healthy school cultures.

\section{Fostering Supportive Working Conditions}

Novices are not the only teachers struggling to survive. All special educators cope with extraordinary challenges. They often face isolation, lack of administrative support, role ambiguity, challenges with classroom management, a multifaceted curriculum, lack of planning time, parental concerns, and a multitude of rules and regulations (Billingsley, 2002; Brownell, Smith, McNellis, \& Miller, 1997; Griffin et al, 2002). Thus, it is no surprise that many succumb to environments that lack adequate school and district support.

Nevertheless, a close examination of the major factors of attrition reveal that most of the issues can be addressed by systematically improving the organizational characteristics and working conditions in schools and districts (Ingersoll, 2001; Rosenholtz, 1991; Yee, 1990). By attending to a healthy school culture, all teachers-general education and special education, early career and veterans-find themselves in a collegial, stimulating environment that allows them to do what they entered the profession to do-teach.

The role of a competent administrative leadership at both the school and district levels is pivotal in retaining general and special education teachers. Effective leadership might ameliorate factors relating to attrition and also create a collaborative work environment in which students, teachers, and learning communities flourish (Brownell \& Skrtic, 2002; Fullan \& Hargreaves, 1991). Within these positive climates exists an "abundant spirit of continuous improvement" (Rosenholtz, 1991, p. 208), and school-level administrators hold the key to teacher retention.

Effective school principals are committed to creating and nurturing a quality teacher workforce. Earlier case studies of teacher commitment and retention suggest that exemplary principals establish a school climate of collegiality and collaboration by (a) fostering ongoing learning, (b) protecting beginning and veteran teachers from forces that inhibit their ability to teach, (c) promoting helping relationships, (d) engaging teachers in shared decision making, and (e) establishing common goals (Rosenholtz, 1991; Yee, 1990).

Principals who exhibit these characteristics also value induction and professional development programs, which in turn establish a sense of self-efficacy and competence and support instructional innovation (Joyce, Calhoun, \& Hopkins, 1999; Yee, 1990). By addressing workload assignments, discipline, and unnecessary district and state edicts, principals allow special education teachers to focus on teaching.

The district and community context also contributes to a teacher's decision to remain in teaching (Ingersoll, 2001; Rosenholtz, 1991; Yee, 1990). In Rosenholtz's (1991) study of eight elementary school districts in Tennessee, she analyzed the effects of district-level practices by interviewing superintendents and high-ranking central office staff members. Profiles of "moving" and "stuck" districts emerged as quantitative and qualitative data were analyzed. The "moving" districts invested in quality induction programs, emphasized the importance of continuous learning, and provided shepherding for their beginning teachers. A high level of commitment for continued professional growth permeated the successful districts. In addition, higher overall retention rates of the teacher workforce occurred in "moving" districts.

\section{CONCLUSIONS ABOUT POLICY AND PRACTICE IN REDUCING SPECIAL EDUCATION TEACHER SHORTAGES}

The teacher-shortage issue is disconcerting, as it threatens the ability of public schools to provide an appropriate education to students with disabilities, particularly in our nation's poorest schools. But existing solutions have the potential to increase the retention of new hires and improve teacher quality. The Connecticut policy approach emphasizes improvement of teaching through standards and professional preparation-policy strategies recommended by NCTAF. It also holds great promise for reducing teacher 
shortages in special education. Clearly, creating state policies and district cultures that promote and reward highquality teaching will improve the recruitment and retention of all teachers.

Unfortunately, many states have not created policy contexts that are as impressive as Connecticut's, nor do they have the political support in their state for doing so. Thus, many teachers, district and state administrators, and higher education faculty may be left wondering what role they can play in improving the supply of new teachers and increasing teacher retention, particularly when there seems to be little legislative will to increase resources to teaching and teacher education. Creating more high-quality alternative preparation programs seems to be one solution that many higher education faculty, sometimes in conjunction with district administrators, are already implementing to improve the supply and retention of teachers. Alternative programs offered to preservice students in remote, rural sites, such as the programs developed by the University of Utah and Utah State University, in collaboration with the state's Comprehensive System of Personnel Development, draw on a population of prospective teachers who are likely to remain in the rural communities in which they live. Other programs, such as one currently offered by Johns Hopkins University in conjunction with the Montgomery Public Schools and funded by OSEP, prepare paraprofessionals intending to become special education teachers. Many OSEP-funded programs, however, are expensive, and the institutional capacity for continuing them without ongoing federal support or additional state support seems unlikely.

State and district administrators can improve recruitment techniques, as the state of Oregon and the Clark County Public Schools have done. Advertising professional programs and benefits over the Internet seems to be a relatively easy, low-cost, and effective way to recruit new teachers. States and districts also should consider devoting funds to furthering the professional development of principals regarding special education and developing induction programs for all beginning teachers. In doing so, though, they must realize that successful mentoring requires training and time and that the needs of beginning special education teachers will be different and extensive.

In addition, states and districts have to collect better data on their efforts to recruit and retain teachers. These data may be used in collaborative efforts with teacher education researchers to identify the factors contributing to teacher shortages in special education and, more important, how to remedy them.

Administrators and teachers also may work together to provide supports at the school level that promote teacher retention and the induction of beginning teachers. Building administrators need to be aware of the barriers that special educators confront as they collaborate with general education teachers and complete procedural and paperwork requirements. As the instructional leaders in a building, principals may foster a vision that focuses on collaboration between special and general education to promote learning for all children. One way they can establish a vision is to create opportunities for special and general educators to work together on schoolwide initiatives, such as implementing a new literacy program or a schoolwide discipline program and determining the impact of these initiatives on student learning. Building administrators also may use resources creatively to assist special educators with paperwork and meetings, and to ensure that they have the same access as their general education counterparts to instructional materials.

Most important, principals and veteran special educators must be cognizant of beginning special education teachers' needs and must provide them the support they require to succeed. Principals and veteran teachers should be ready to provide advice and hands-on support to beginners who are struggling with behavioral and instructional problems. Principals may provide release time for veteran special educators to observe and coach their novice colleagues. Veteran special educators and principals must communicate frequently with new teachers about the issues they are confronting and help them find solutions. Only by promoting continuous teacher learning and collegiality in a supportive, healthy work environment can principals and teachers create schools that retain special education teachers.

Finally, state administrators, district administrators, teacher educators, and teachers need to collaborate in strategic efforts to educate the public about the teacher shortage and quality issues. Connecticut is a good example of how an educated public will support system-wide school reform.

\section{REFERENCES}

American Association for Employment in Education (AAEE) (1999). Educator supply and demand. Columbus, OH: AAEE.

Andrew, M. D., \& Schwab, R. L. (1995). Has reform in teacher education influenced teacher performance? An outcome assessment of graduates of an eleven-university consortium. Action in Teacher Education, 17, 43-53.

Baron, J. B. (1999). Exploring high and improving reading achievement in Connecticut. Washington, DC: National Educational Goals Panel.

Berry, B. (2001). No shortcuts to preparing good teachers. Educational Leadership, 58, 32-36.

Billingsley, B. S. (1993). Teacher retention and attrition in special and general education: A critical review of the literature. Journal of Special Education, 27(2), 137-174.

Billingsley, B. S. (2001). Beginning special educators: Characteristics, qualifications, and experiences: SPeNSE summary sheet. Retrieved October, 2002, from http://www.SPeNCE.org

Billingsley, B. S. (2002). Special education teacher retention and attrition: A critical analysis of the literature. Gainesville, FL: University of Florida: Center on Personnel Studies in Special Education (COPSSE). 
Billingsley, B., \& Cross, L. (1992). Predictors of commitment, job satisfaction, and intent to stay in teaching: A comparison of general and special educators. The Journal of Special Education, 25, 453-471.

Billingsley, B. Pyecha, J., Smith-Davis, J., Murray, K., \& Hendricks, M. (1995). Improving the retention of special education teachers: Final report. Research Triangle Institute (Prepared for Office of Special Education Programs, Office of Special Education and Rehabilitative Services, The U.S. Department of Education under Cooperative Agreement H023Q10001. (ERIC Document Reproduction Service No. ED 379860 )

Billingsley, B. S., \& Tomchin, E. M. (1992). Four beginning LD teachers: What their experiences suggest for trainers and employers. Learning Disabilities Research and Practice, 7(2), 104-112.

Boe, E. E., Barkanic, G., \& Leow, C. S. (1999). Retention and attrition of teachers at the school level: National trends and predictors (Data Analysis Rep. No. 1999-DAR1. Philadelphia: University of Pennsylvania. ERIC Document Reproduction Service No. ED436 485).

Boe, E. E., Cook, L. H., Bobbitt, S. A., \& Weber, A. L. (1996). Retention and attrition of teachers at the district level: National trends in special and general education. Research Rep. No. 1996-TSD6 (ED410742). Philadelphia: Pennsylvania Univ. Philadelphia, Center for Research and Evaluation in Social Policy.

Boyer, L., \& Gillespie, P. (2000). Keeping the committed: The importance of induction and support programs for new special educators. Teaching Exceptional Children, 33, 10-15.

Boyer, L., \& Lee, C. (2001). Converting challenge to success: Supporting a new teacher of students with autism. Journal of Special Education, $35,75-83$.

Brownell, M. T., \& Skrtic, T. (2002). Assuring an adequate supply of wellqualified teachers to improve the educational outcomes of students with disabilities. Testimony provided to President's Commission on Excellence in Special Education Professional Development Task Force.

Brownell, M. T., \& Smith, S. W. (1992). Attrition/retention of special education teachers: Critique of current research and recommendations for retention efforts. Teacher Education and Special Education, 15, 229-248.

Brownell, M. T., Smith, S. W., McNellis, J. R., \& Miller, M. D. (1997). Attrition in special education: Why teachers leave the classroom and where they go. Exceptionality, 7, 143-155.

Bureau of Labor Statistics (1999). National industry-occupation employment matrix: Occupation report-teachers, special education. Retrieved August 23, 2001 from http://www.bls.gov/ooq/2000/spring/contents. html

Carlson, E., \& Billingsley, B. S. (2001, July). Working conditions in special education: Current research and implications for the Field. Paper presented at OSEP Project Directors' Conference, Washington, DC.

Carlson, E., Schroll, K., \& Klein, S. (2001). OSEP briefing on the study of personnel needs in special education (SPeNSE). Retrieved August 24, 2001, from www.spense.org/results.html

Carter, K. B., \& Scruggs, T. E. (2001). Thirty-one students: Reflections of a first-year teacher of students with mental retardation. Journal of Special Education, 35, 100-104.

Cross, L. H., \& Billingsley, B. S. (1994). Testing a model of special educators' intent to stay in teaching. Exceptional Children, 60, 411-421.

Darling-Hammond, L. (1997). Doing what matters most: Investing in quality teaching. New York: National Commission on Teaching and America's Future.

Darling-Hammond, L. (1999). Solving the dilemmas of teacher supply, demand, and standards. New York: National Commission on Teaching and America's Future.

Darling-Hammond, L., Chung, R., \& Frelow, F. (2002). Variation in teacher preparation: How well do different pathways prepare teachers to teach? Journal of Teacher Education, 53, 286-302.

Embich, J. L. (2001). The relationship of secondary special education teachers' roles and factors that lead to professional burnout. Teacher Education and Special Education, 24, 58-69.

Epanchin, B. C., \& Wooley-Brown, C. (1993). A university-school district collaborative project for preparing paraprofessionals to become special educators. Teacher Education and Special Education, 16, 110-123.
Focus: Pathways. A periodic report on grantmaking programs of the DeWitt Wallace Reader's Digest Fund (n.d.) Retrieved on November 27, 2002 from http://www.wallacefunds.org/publications/pub_teach/

Fullan, M., \& Hargreaves, A. (1991). What's worth fighting for in your school?: Working together for improvement. Buckingham, United Kingdom: Open University Press.

Gaynor, J. F., \& Little, M. E. (1997). The expanding role of LEAs in special education teacher preparation: The view from a local school district. Teacher Education and Special Education, 20, 281-300.

Gersten, R., Keating, T., Yovanoff, P., \& Harniss, M. K. (2001). Working in special education: Factors that enhance special educators' intent to stay. Exceptional Children, 67, 546-567.

Gibb, G. S., \& Welch, M. (1998). The Utah Mentor Teacher Academy: Evaluation of a Statewide Mentor Program. Teacher Education and Special Education, 21, 22-33.

Griffin, C. C., Winn, J., Otis-Wilborn, A., \& Kilgore, K. L. (2002). New teacher induction in special education. Center on Personnel Studies in Special Education. Retrieved October 1, 2002, from http://www.copsse.org/

Haberman, M. (1999). Increasing the number of high-quality African American teachers in urban schools. Journal of Instructional Psychology, 26, 208-212.

Hanushek, E., Kain, J. F., \& Rivkin, S. G. (2001). Why public schools lose teachers. Cambridge, MA: National Bureau of Economic Research.

Hare, D., \& Heap, J. L. (2001). Effective teacher recruitment and retention strategies in the Midwest: Who is making use of them? North Central Regional Education Laboratory. Retrieved October 16, 2002, from http://www.ncrel.org/policy/pubs/html/strategy/index.html

Henke, R. R., Chen, X., Geis, S., \& Knepper, P. (2000). Progress through the Teacher Pipeline: 1992-93. College graduates and elementary/ secondary school teaching as of 1997. Education Statistics Quarterly, 2, 91-98.

Hirsch, E., Koppich, J. E., \& Knapp, M. S. (1998). State action to improve teaching (Policy brief). Seattle: Center for the Study of Teaching and Policy.

Hirsch, E., Koppich, J. E., \& Knapp, M. S. (2001). Revisiting what states are doing to improve the quality of teaching: An update on patterns and trends. Center for the Study of Teaching and Policy. Retrieved August 27, 2001, from University of Washington, Center for the Study of Teaching and Policy website: http://depts.washington.edu/ctpmail

Ingersoll, R. M. (2001). Teacher turnover, teacher shortages, and the organization of schools (ED445415). Paper presented, in part, at annual meeting of American Sociological Association, Center for the Study of Teaching and Policy, Seattle.

Joyce, B., Calhoun, E., \& Hopkins, D. (1999). The new structure of school improvement: Inquiring schools and achieving students. Philadelphia: Open University Press.

\section{STATEMENT OF OWNERSHIP, MANAGEMENT AND CIRCULATION}

Date of Filing: Dec. 5, 2002 / Title of Publication: Focus on Exceptional Children

Frequency of Issue: Monthly (except June, July \& August) / Location of Known Office of Publication: 9101 E. Kenyon Ave., Suite 2200, Denver, CO 80237 / Location of Headquarters of Publisher: 9101 E. Kenyon Ave., Suite 2200, Denver, CO 80237

Name and Address of Publisher, Editor, and Managing Editor: Stanley F. Love, 9101 E. Kenyon Ave., Suite 2200, Denver, CO 80237

Owner: Love Publishing Company

Extent and Nature of Circulation:

Total No. Copies Printed

Paid Circulation

Sales through Dealers, etc.

Mail Subscriptions

Other Classes Mailed

Total Paid Circulation

Free Distribution

Total Distribution

Office Use and Left Over

Total

Average No Copies Each Issue During Preceding 12 Months 1640

Single Issue Nearest

Filing Date 1555

I certify that the statements made by me above are correct and complete.

280
1204
39
1523
32
1555
0
1555

280

423
1135
46

46

1604
36

1640

0

1640 
Kilgore, K. L., \& Griffin, C. C. (1998). Beginning special educators: Problems of practice and the influence of school context. Teacher Education and Special Education, 21, 155-173.

Kozleski, E., Mainzer, R., \& Deshler, D. (2000). Bright Futures for Exceptional Learners: An Agenda To Achieve Quality Conditions for Teaching \& Learning. Arlington VA: Council for Exceptional Children.

Laczko-Kerr, I., \& Berliner, D. C. (2002, September 6). The effectiveness of "Teach for America" and other under-certified teacher on student academic achievement: A case of harmful public policy. Education Policy Analysis Archives, 10(37). Retrieved December 19, 2002, from http://epaa.asu.edu/epaa/v10n37/

MacDonald, V. (2001). Making time: A teacher's report on her first year of teaching children with emotional disabilities. Retrieved October 15, 2002 from http://www.findarticles.com/cf 0/m0HDF/2 35/77813333/ print.jhtml

Mastropieri, M. A. (2001). Is the glass half full or half empty? Challenges encountered by first-year special education teachers. Journal of Special Education, 35, 66-74.

McLeskey, J., Smith, D. D., Tyler, N., \& Saunder, S. (2002). The supply of and demand for special education teachers: A review of research regarding the nature of the chronic shortage of special education. Gainesville, FL: COPSSE.

Miller, M. D., Brownell, M. T., \& Smith, S. W. (1999). Factors that predict teachers staying in, leaving, or transferring from the special education classroom. Exceptional Children, 65, 201-218.

Miller, J. W., McKenna, M. C., \& McKenna, B. A. (1998). A comparison of alternatively and traditionally prepared teachers. Journal of Teacher Education, 49, 165-176.

Morvant, M., Gersten, R., Gillman, J., Keating, T., \& Blake, G. (1995). Attrition/retention of urban special education teachers: Multi-faceted research and strategic action planning (Final Performance Rep., Vol. 1). (ERIC Document Reproduction Service No. ED 338 154)

Moskowitz, J., \& Stephens, M. (Eds.) (1996). From students of teaching to teachers to students: Teacher induction around the Pacific Rim. Washington, DC: U.S. Department of Education for Asia-Pacific Economic Cooperation.

National Association of State Directors of Teacher Education and Certification. (2000). The NASDTEC manual on the preparation and certification of educational personnel (5th ed.). Dubuque, IA: Kendall/ Hunt.

National Association of State Directors of Teacher Education and Certification. (2002). The NASDTEC manual on the preparation and certification of educational personnel (7th ed.). Dubuque, IA: Kendall/ Hunt.

National Center for Education Information (1998). Profile of Troops to Teachers. Retrieved on December 20, 2002 from http://www.dantes. doded.mil/Dantes_web/troopstoteachers/profile.htm

National Center for Educational Statistics (1997). Digest of education statistics, 1997. Washington, DC: U.S. Department of Education.

National Commission on Teaching and America's Future. (1996). What matters most: Teaching for America's future. New York: Author.

No Child Left Behind. Retrieved December 10, 2002, from http://www.ed. gov/legistration/ESEA02

Olson, L. (2000). Finding and keeping competent teachers. Quality counts: Who should teach. Education Week Special Issue, 19, 12-17.

Pogodzinski, J. M. (2000). The teacher shortage: Cause and recommendations for change. San Jose, CA: California Senate Office of Research.

Oregon Special Education Recruitment and Retention Project. (2002). Detail findings related to recruiting special education personnel. Teaching Research, Western Oregon University. Monmouth, OR. Retrieved October 9, 2002, from http://www.tr.wou.edu/rrp/surveyresults.htm

Rennells, M. S., Sindelar, P. T., \& Austrich, C. (1997). Volusia County/University of Florida collaborative training program case study. Gainesville: University of Florida, Department of Special Education, Project SEART-C (Technical Rep. No. 8).

Riley, R. (1998). Our teachers should be excellent, and they should look like America. Education and Urban Society, 31, 18-29.
Rosenberg, M. S., Griffin, C. C., Kilgore, K. L., \& Carpenter, S. L. (1997). Beginning Teachers in Special Education: A model for providing individualized support. Teacher Education and Special Education, 20, 301-321.

Rosenberg, M. S., \& Rock, E. E. (1994). Alternative certification in special education: Efficacy of a collaborative, field-based teacher preparation program. Teacher Education and Special Education, 17, 141-153.

Rosenberg, M. S., \& Sindelar, P. T. (2001). The proliferation of alternative routes to certification in special education: A critical review of the literature. Arlington, VA: Council for Exceptional Children, National Clearing for Professionals in Special Education.

Rosenholtz, S. J. (1991). Teachers' workplace: The social organization of schools. White Plains, New York: Longman.

Schnorr, J. (1995). Teacher retention: A CSPD analysis and planning model. Teacher Education and Special Education, 18, 22-38.

Silva, J. M., \& Silva, D. (2001). Year two: BCPSS mentor programs (Status Report). Gainesville: University of Florida.

Sindelar, P. T., Rennells, M. S., Daunic, A. Austrich, C., \& Eisele, M. (1999). Systematic evaluation of alternative routes to teaching competence: Project SEART-C final report. Gainesville, FL: Center for School Improvement (Technical Rep. No. 10).

Singer, J. D. (1993). Are special educators' career paths special? Results from a 13-year longitudinal study. Exceptional Children, 59, 262-279.

Singh, K., \& Billingsley, B. S. (1996). Intent to stay in teaching: Teachers of students with emotional disorders versus other special educators. Remedial and Special Education, 17, 37-47.

Southeast Center for Teacher Quality. (January 2002). Recruitment and retention strategies in a regional and national context [Electronic Report]. Southeast Center for Teaching Quality Recruitment and Retention Strategies. Retrieved September 2, 2002, from http://www.teaching quality.org/resources/articles.htm

U.S. Department of Education (1998). Special education teachers: National trends and demand and shortage (Section III, pp. 1-23). In USDOE (Ed), Twentieth annual report to Congress on the implementation of the Individuals with Disabilities Education Act. Washington, DC: Author.

U.S. Department of Education (1998). Twentieth annual report to Congress on the implementation of the Individuals with Disabilities Education Act. Washington, DC: Author.

U.S. Department of Education (2000). Twenty-second Annual Report to Congress on the Implementation of the Individuals with Disabilities Education Act. Washington, DC: Author.

U.S. Department of Education (2001). Annual report tables: IDEA Part B Personnel (1998-99), Table $A C^{l}$ and $A C^{2}$. Retrieved August 23, 2001 from www.ideadata.org/arc_toc.html\#partbCC

U.S. Department of Education (2002). Meeting the Highly Qualified Teachers Challenge: The Secretary's Annual Report on Teacher Quality: U.S. Department of Education, Office of Postsecondary Education.

Webber, J., Raffeld, P., \& Kettler, M. (n.d.). Troops as teachers in Texas are they effective? Research report.

West, J. (2002, November). Highly qualified special education teachers: The policy debate. Paper presented at annual meeting of Teacher Education Division of Council for Exceptional Children, Savannah, GA.

Westling, D. L., \& Whitten, T., M. (1996). Rural special education teachers' plans to continue or leave their teaching positions. Exceptional Children, 62, 319-335.

White, M., \& Mason, C. (2001). Mentoring induction principles and guidelines (draft). Arlington, VA: Council for Exceptional Children.

Whitaker, S. D. (2000). Mentoring beginning special education teachers and the relationship to attrition. Exceptional Children, 6, 546-566.

Wilson, S. M., Darling-Hammond, L., \& Berry, B. (2001). A case of successful teaching policy: Connecticut's long-term efforts to improve teaching and learning. Seattle: University of Washington.

Yee, S. M. (1990). Careers in the classroom: When teaching is more than a job. New York: Teachers College Press.

Zeichner, K. M., \& Schulte, A. K. (2001). What we know and don't know from peer-reviewed research about alternative teacher certification programs. Journal of Teacher Education, 52, 266-282. 


\section{RESOURCES}

\section{Sites of Interest to Teachers}

Beginning and Preservice Teachers, www.sabine.k12.la.us/vrschool/newteachers.htm

A website providing support and insight for new and beginning teachers.

LD Online, www.ldonline.org

A user-friendly website for parents, teachers and other professionals involved in the area of special education.

National Staff Development Council, www.nsdc.org

A robust site for information on staff development for educators:

addresses issues of teacher quality, staff development, and school improvement.

New Teacher Center, www.newteachercenter.org

Website hosted by the University of California at Santa Cruz that is dedicated to teacher development and new teacher training.

Recruiting New Teachers, www.rnt.org

A website offering guidance and resources for prospective teachers, as well as information and research on current trends and issues in the field.

Special Education News, www.specialednews.com

A website that offers unique resources to special education professionals. Topics include educating students with disabilities as well as special education news and events across the country.

Teachers.Net $\boldsymbol{w} w \boldsymbol{w}$.teachers.net

A supportive site for beginning and experienced teachers.

\section{Sites of Interest to Administrators}

\section{Beginning Teacher Center,}

\section{http://www.teachers21.org/teachers21beginteachcntr.asp}

A website that promotes teacher quality and focuses on beginning teachers as well as the retention of new teachers.

Center on Personnel Studies in Special Education www.copsse.org A comprehensive website composed of research syntheses and issue briefs on special education. The Center of Personnel Studies in Special Education, COPSSE, is a cooperative agreement between the U.S. Department of Education, Office of Special Education Programs, and the University of Florida. COPSSE scholars are seeking answers to questions that have long bedeviled the field of special education.
Center for the Study of Teaching and Policy http://depts.washington.edu/ctpmail/

A comprehensive website housed at the University of Washington that addresses the many issues surrounding education: teacher quality, beginning teachers, teacher preparation, teacher shortages, and teacher development.

Ed Policy Research Center, www.edpolicy.org/research Website that provides information on education policy at the national, regional, and state levels; among the numerous topics included in the site are teacher preparation, certification, professional development, and mentoring issues.

Education Commission of the States, www.ecs.org

A website created to improve public education by facilitating the exchange of information, ideas, and experiences among state policy makers and education leaders; site contains information on current education research and issues.

National Teacher Recruitment Clearinghouse,

\section{www.recruitingteachers.org}

A website designed to help meet the challenges of recruiting qualified teachers; provides job opening lists as well as resources and strategies for improving teacher recruitment and retention.

Southeast Center for Teaching Quality, www.teachingquality.org An indepth website addressing the various issues of teaching quality; site includes research on successful teaching and learning practices, as well as research on teacher quality experiences of states and local schools.

Study of Personnel Needs in Special Education, $w w w . S P e N S E . o r g$ Website designed to address the concerns of special education teacher shortages and the need for improvement in the qualifications of those employed in the field. The site also provides information on the quality of the workforce nationally and within each geographic region.

WestEd, www.wested.org

A comprehensive website dedicated in providing resources, as well as addressing the many issues surrounding the field of education. 